International Journal of Current Microbiology and Applied Sciences

ISSN: 2319-7706 Volume 10 Number 09 (2021)

Journal homepage: http://www.ijcmas.com

\title{
Chronic Toxicity Study of Aqueous Roots Extract of Rauvolfia vomitoria AFZEL on Haematological Parameters in Wistar Rats
}

\author{
Roland Patrick N'Cho ${ }^{1 *}$, Mama Koné ${ }^{1}$, Moussa Gbogbo', \\ N'Guessan Jean Baptiste Oussou ${ }^{1}$ and Angoué Paul Yapo ${ }^{1}$
}

\author{
${ }^{1}$ Laboratory of Physiology, Pharmacology and Pharmacopoeia, UFR-SN, \\ University of Nangui Abrogoua, P.O.Box 801, Abidjan 02, Côte d'Ivoire \\ ${ }^{2}$ Department of Biochemistry and Microbiology, Lorougnon Guédé University Daloa, \\ P.O.Box 150, Daloa, Côte d'Ivoire
}

*Corresponding author

\section{A B S T R A C T}

Keywords

Rauvolfia

vomitoria, chronic

toxicity,

haematological

parameters,

reversibility, rats

Article Info

Accepted:

20 August 2021

Available Online:

10 September 2021
Rauvolfia vomitoria Afzel. (Apocynaceae) is a plant used in traditional medicine in Côte d'Ivoire for the treatment of several conditions. This work aims to evaluate the effects of repeated oral administration of the aqueous roots extract Rauvolfia vomitoria AFZEL (AERv) on haematological parameters in Wistar rats. Thus, 100 healthy rats were divided into four groups (T, A, B, C) of 20 rats each. The sub groups $\mathrm{Ts}$ and $\mathrm{Cs}$ from the groups $\mathrm{T}$ and $\mathrm{C}$ included 10 rats $(5$ males and 5 females) were formed for a reversibility study. After 6 months (180 days) of the experiment, the sub groups rats Ts and Cs were no more treated with the extract till the $210^{\text {th }}$ day ( 7 months), day of their sacrifice to verify the reversibility and/or delayed effects of AERv. The erythrocyte, platelet and leukocyte parameters were determined. Results showed that AERv caused a significant decrease in erythrocyte and thrombocyte parameters with the high dose $(1000 \mathrm{mg} / \mathrm{kg} \mathrm{bw})$ while an increase in leukocyte parameters was noted in a dose-dependent manner. The aqueous extract of the barkless roots is not harmful at the therapeutic dose of $700 \mathrm{mg} / \mathrm{kg}$ bw on the haematological parameters. After stoping administration the effects were reversible.

\section{Introduction}

Traditional medicine occupies a prominent place in primary health care policy in developing countries. Almost $80 \%$ of the population of these countries use it (Aké Assi et Guinko, 1991). The widespread use of traditional medicine is attributed to its integration into the belief systemsof these populations but also to its accessibility and affordability (OMS, 2002). In this context for several years, African medicinal plants have 
been the subject of several research works which, have favored the descriptive inventory of plants and recipes (Adjanohoun and Aké Assi, 1979; Aké Assi, 1983). Now, knowledge on the properties of plants commonly used in the African pharmacopoeia is a matter of urgency due to the growing number of poisonings and complications related to their use (Neuwinger, 1996). Thus, WHO (OMS, 2002) recommends that a minimum of scientific studies be carried out on medicinal plants in order to establish a scientific basis. It is in this context that N'Doua et al., (2016) set out to study the effectiveness of the aqueous extract of the roots of Rauvolfia vomitoria (Apocynaceae), a plant used in Côte d'Ivoire in the treatment of several conditions such as rheumatism, diarrhea, malaria, high blood pressure and especially diabetes. This study showed that oral administration of the aqueous extract of the barkless roots of Rauvolfia vomitoria (AERv) at doses of 500, 700 and $1000 \mathrm{mg} / \mathrm{kg}$ bw to normoglycemic rats, resulted in a dose-dependent decrease in blood glucose.

This extract similarly reduced hyperglycemia induced by oral administration of $4 \mathrm{~g} / \mathrm{kg}$ bw of glucose to healthy rats, this effect was otherwise similar to that of glibenclamide at $10 \mathrm{mg} / \mathrm{kg}$ bw.

In addition, the acute toxicity study has shown that the $50 \%$ lethal dose (LD50) by the oral route is higher than $5000 \mathrm{mg} / \mathrm{kg}$ bw, thus proving its safety in an acute administration (N'Doua et al., 2016). However, since diabetes is a chronic disease, it would be indicated as recommended by the FDA (1999), to assess the safety of this extract in a chronic toxicity test. With this in mind that this work has set itself the objective of the safety of the aqueous extract of the roots of Rauvolfia vomitoria (Apocynaceae) on hematological parameters in rats for six months.

\section{Materials and Methods}

\section{Plant material}

The roots of Rauvolfia vomitoria. were collected in December 2016 in Padiégnan s/p of Yakassé Féyassé in the department of Abengourou, $210 \mathrm{~km}$ from Abidjan (Côte d'Ivoire). A sample of the plant was provided by N'Doua et al., (2016). The plant has been identified and authenticated at the National Floristic Center (C.N.F), University of Félix Houphouët-Boigny in Cocody-Abidjan.

\section{Animal material}

Albino rats of the species Rattus norvegicus, male and female, healthy, nulliparous and non-pregnant, 6 to 8 weeks old and weighing between 80 and $100 \mathrm{~g}$ were used for the tests. The animals were kept in the animal house of Laboratory of Physiology, Pharmacology and Pharmacopoeia of University Nangui Abrogoua (Abidjan, Côte d'Ivoire). They were put in plastic cages with a stainless steel cover fitted with feeding bottles. All animals were subjected to a temperature of $25^{\circ} \mathrm{C} \pm 2$ with alternating 12 hours of light and 12 hours of darkness. The diet consisted of IVOGRAIN® granules and the rats were provided with tap water ad libithum. The experimental protocol and animal handling procedures were conducted according to good laboratory practice (OCDE, 2009).

\section{Preparation of the aqueous roots extract of Rauvolfia vomitoria}

The extracts were prepared according to the extraction method described by N'Doua et al., (2016). The roots stripped of the bark were cut into small pieces, crushed using a mortar, then dried at room temperature $\left(25^{\circ} \mathrm{C} \pm 2\right)$ for a week. They were pulverized using an electric grinder (Culatti, France). The aqueous extract was obtained following a maceration under a 
magnetic stirrer of $200 \mathrm{~g}$ of Rauvolfia vomitoria root powder in 2 liters of water for 24 hours. The macerate is filtered three times through cotton wool and Wattman $\mathrm{N}^{\mathrm{O}} 1$ paper dried at $40^{\circ} \mathrm{C}$ in an oven for 48 hours. The powder $(13.5 \mathrm{~g})$ obtained constitutes the aqueous root extract of Rauvolfia vomitoria (AERv).

\section{Chronic toxicity study}

OECD Guideline 452 (OCDE, 2009) was used to conduct the chronic toxicity study. So hundred (100) healthy rats were divided into four groups (T, A, B, C) of 20 rats each, including 10 males and 10 females per batch. sub groups $\mathrm{Ts}$ and $\mathrm{Cs}$ from group $\mathrm{T}$ and $\mathrm{C}$ included 10 rats (5 males and 5 females) for the reversibility study. They received by gavage using a cannula, $2 \mathrm{ml} / 100 \mathrm{~g}$ bw of the extract once a day at the same time $(8 \mathrm{~h} 00$ min) for 6 months (180 days). The different administrations were as followed: Lots $\mathrm{T}$ and Ts received distilled water; Group A and B, respectively received the aqueous extract at doses of 500 and $700 \mathrm{mg} / \mathrm{kg}$ bw respectively; Groups $\mathrm{C}$ and $\mathrm{Cs}$ received AERv at a dose of $1000 \mathrm{mg} / \mathrm{kg}$ bw.

\section{Study of the persistence or reversibility of} the extract

The day after the 180th day (6th month) of the experiment, the rats of the Ts and Cs sub groups were no more treated with the extract till the $210^{\text {th }}$ day ( 7 months), day of their sacrifice.

\section{Biological blood tests}

Blood samples were taken from the retroorbital sinus of the rats according to the method described by Waynforth (1980) at each period indicating the various toxicity studies: after 30 days (subacute toxicity); after 90 days (subchronic toxicity) after; 180 days (chronic toxicity) and after 210 days (reversibility test). This, rats were fasted the day before, they were anesthetized with COOPER ether and then the blood was drawn using a sterile pasteur pipette. Approximately 0.5 to $1 \mathrm{ml}$ of blood was collected in tubes containing the anticoagulant ethylene diamine tetra acetic acid (EDTA) for blood count cells (CBC) using a Mindray BC 30S $®$ automatic analyzer. The levels of erythrocytes, hemoglobin, hematocrit, leukocytes, and thrombocytes were determined (Langford et al., 2003). Blood smears were also performed according the method describing by Kouassi, et al., (2018).

\section{Statistical analysis of data}

The data were analyzed using Graph Pad Prism 8.0.1 (244) software. The results obtained are expressed as the mean followed by the standard error on the mean $(\mathrm{M} \pm \mathrm{ESM})$. The difference between the mean values of the parameters were be determined by the twoway analysis of variance (ANOVA 2) to check the normality of the variables within each group and the homogeneity of the variances. The threshold of significance was set at $\mathrm{p}<$ 0,05 . The asterisks $(*, * *, * * *)$ indicated a significant decreases while the letters $(a, b, c)$ expressed significant increases compared to the controls.

\section{Results and Discussion}

Effect of AERv on erythrocytes and erythrocyte indices in male and female rats

The results showed that, AERv in male rats at all doses did not change erythrocyte count compared to controls at all (Figure 1A).The same after 6 months of treatment.the extract at 500 and $700 \mathrm{mg} / \mathrm{kg}$ bw. AERv $(1000 \mathrm{mg} / \mathrm{kg}$ bw) significantly reduced $(\mathrm{p}<0.01)$ the level erythrocyte. AERv had the same effect on erythrocytes in female rats (Figure 1B). 
Regarding hemoglobin, repeated administration of different doses of AERv did not disturb the values at the dose of 500 and $700 \mathrm{mg} / \mathrm{kg}$ bw in both male and female rats throughout the experiment (Figure 2A and 2B). However, just like erythrocytes the dose of $1000 \mathrm{mg} / \mathrm{kg}$ bw resulted in a significant decrease $(\mathrm{p}<0.05)$ in hemoglobin level (Figure 2A) at month 6, only in male rats. The hematocrit level remained close in both treated and control group up to month 6 (Figure 3A and 3B). Only $1000 \mathrm{mg} / \mathrm{kg}$ bw of AERv induced a significant decrease $(\mathrm{p}<0.001)$ at the end of treatment. Regarding the anomalies, microcytosis (Figure $5 \mathrm{C}$ and $6 \mathrm{C}$ ) were present significative in male rats $40 \%(\mathrm{p}<$ $0.05)$ and female rats $50 \%(\mathrm{p}<0.05$ at 1000 $\mathrm{mg} / \mathrm{kg}$ bw. However, the presence of schizocytes (Figure $5 \mathrm{D}$ and $6 \mathrm{D}$ ) is noted in the rats which received $700 \mathrm{mg} / \mathrm{kg}$ bw at a proportion of $10 \%$. at $1000 \mathrm{mg} / \mathrm{kg}$ bw of AERv induced schizocytes at a rate of $30 \%(\mathrm{p}$ $<0.05$ ) in the male rats and $20 \%$ not significant in the female (Table 1).

\section{Effect of AERv on Leukocyte Parameters in Male and Female Rats}

On the level of leukocytes, no disturbance was noted in all the rats treated with the dose of $500 \mathrm{mg} / \mathrm{kg}$ bw compared to the controls (Figures 4A and 4B). However, the AERv showed a significant increase $(\mathrm{p}<0.05)$ only on the third month with the dose of $700 \mathrm{mg} / \mathrm{kg}$ bw in male rats while in female rats this increase occurred in the first and third months. In rats treated with the $1000 \mathrm{mg} / \mathrm{kg}$ bw of $\mathrm{AERv}$, an increase in leukocytes was observed during all the periods of administration.

\section{Effect of AERv on Thrombocytes in male and female rats}

The extract did not cause any significant change in thrombocytes in all rats during the first month (month 1) (Table 2). However, a very significant decrease $(\mathrm{p}<0.001)$ in thrombocytes was observed in both treated male and female rats, in a dose-dependent manner from the third month (month 3 ) until the end of the sixth month (month 6).

\section{Reversible and delayed effect of AERv on the haematological parameters of rats}

At the highest dose of $1000 \mathrm{mg} / \mathrm{kg}$ bw, after one month of stopping the extract, the erythrocyte parameters which were significantly low compared to the controls values similar to those of the controls, both in males and in females (Table 3). This to normal values is also observed in the thrombocytes (Table 3). Indeed, the leukocyte level which was high $(\mathrm{p}<0.001)$ at Month $6(\mathrm{p}<0.01$ and $\mathrm{p}<0.001)$ in all rats treated with $1000 \mathrm{mg} / \mathrm{kg}$ bw of EARv, at Month 7 normalized. in female rats and very significantly decreased ( $p$ $<0.001$ ) in male rats. As for the effect of EARv on blood tissue integrity in rats, the observed abnormalities are reversible after stopping the administration one month later.

\section{Effet de EARv sur l'intégrité tissulaire sanguine des rats}

AERv caused a sharp decrease in red blood cells, hematocrit levels in both male and female rats at the end of the experiment with $1000 \mathrm{mg} / \mathrm{kg}$ bw of the extract. Our results are similar to those obtained by Gome. et al.,(2011) which reported a decrease in the number of erythrocytes in rats treated with aqueous extract of Passiflora foetida L. Some authors associated the decrease in these parameters with an inhibition of erythrocyte production or their destruction by the presence of saponins (Arias et al., 2010). However, N'Doua et al., (2016) revealed the presence of saponins in the aqueous extract of the barkless root extract of Rauvolfia vomitoria. 
Fig.1 Effect of total aqueous root extract of Rauvolfia vomitoria (AERv) on erythrocytes of male and female rats as a function of time
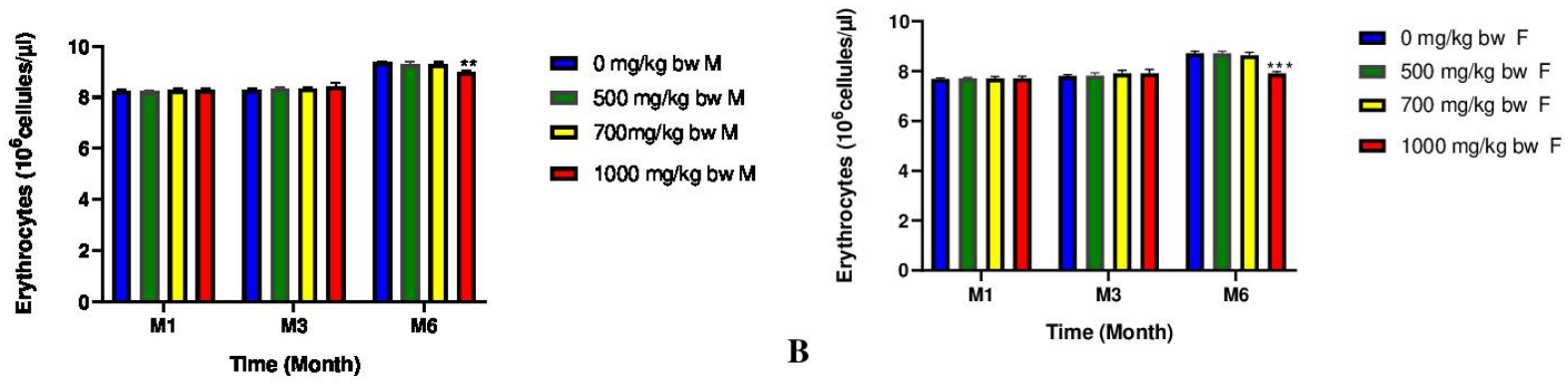

A: in male rats; B: in female rats. M: Male ; F: Female. Each bar represents the mean \pm standard error on the mean $(\mathrm{M} \pm \mathrm{ESM}) ; \mathrm{M} 1, \mathrm{M} 3$ and $\mathrm{M} 6=1,3$ and 6 months of administration; $\mathrm{n}=10$ rats; $* *=\mathrm{p}<0.01, * * *=\mathrm{p}<0.001$

Fig.2 Effect of total aqueous root extract of Rauvolfia vomitoria (AERv) on hemoglobin in Males and females rats
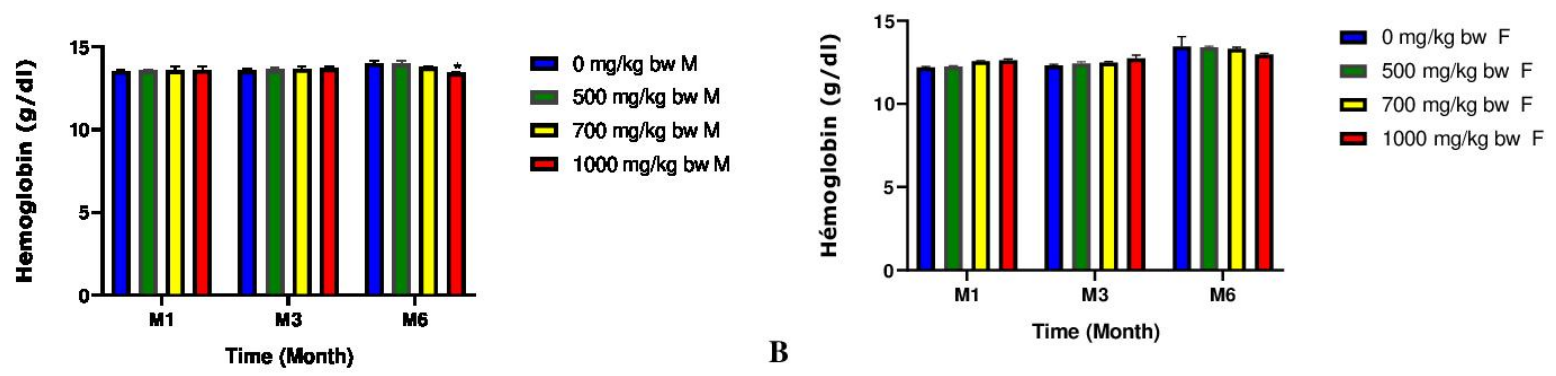

$\mathbf{A}$

A: in male rats; $\mathbf{B}$ in female rats. M: Male ; F: Female. Each bar represents the mean \pm standard error on the mean $(\mathrm{M} \pm \mathrm{ESM}) ; \mathrm{M} 1, \mathrm{M} 3$ and $\mathrm{M} 6=1,3$ and 6 months of administration; $\mathrm{n}=10$ rats, $*=\mathrm{p}<0.05$

Fig.3 Effect of total aqueous root extract of Rauvolfia vomitoria (AERv) on the hematocrit level of male and female rats over time

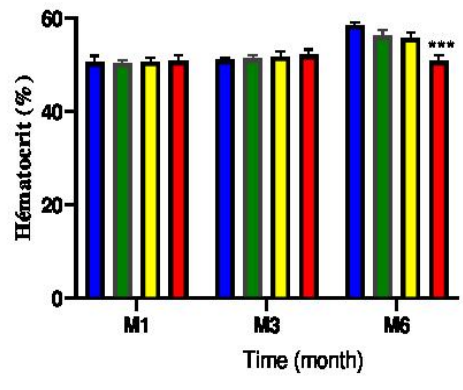

$\mathbf{A}$

A: in male rats; $\mathbf{B}$ in female rats. M: Male ; F: Female. Each bar represents the mean \pm standard error on the mean $(\mathrm{M} \pm \mathrm{ESM}) ; \mathrm{M} 1, \mathrm{M} 3$ and $\mathrm{M} 6=1,3$ and 6 months of administration; $\mathrm{n}=10$ rats, $* * *=\mathrm{p}<0.001$ 
Fig.4 Effect of total aqueous root extract of Rauvolfia vomitoria (AERv) on leukocytes in male and female rats
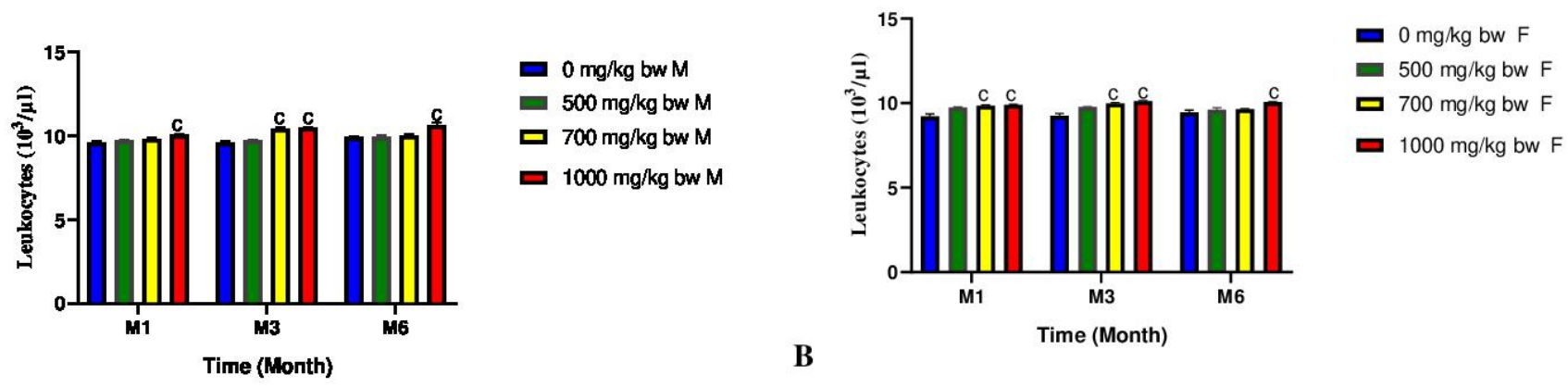

A: in male rats; $\mathbf{B}$ in female rats. M: Male ; F: Female. Each bar represents the mean \pm standard error on the mean $(\mathrm{M} \pm \mathrm{ESM}) ; \mathrm{M} 1, \mathrm{M} 3$ and $\mathrm{M} 6=1,3$ and 6 months of administration; $\mathrm{n}=10$ rats; $\mathrm{c}=\mathrm{p}<0.001$

Fig.5 Blood smear from male rats
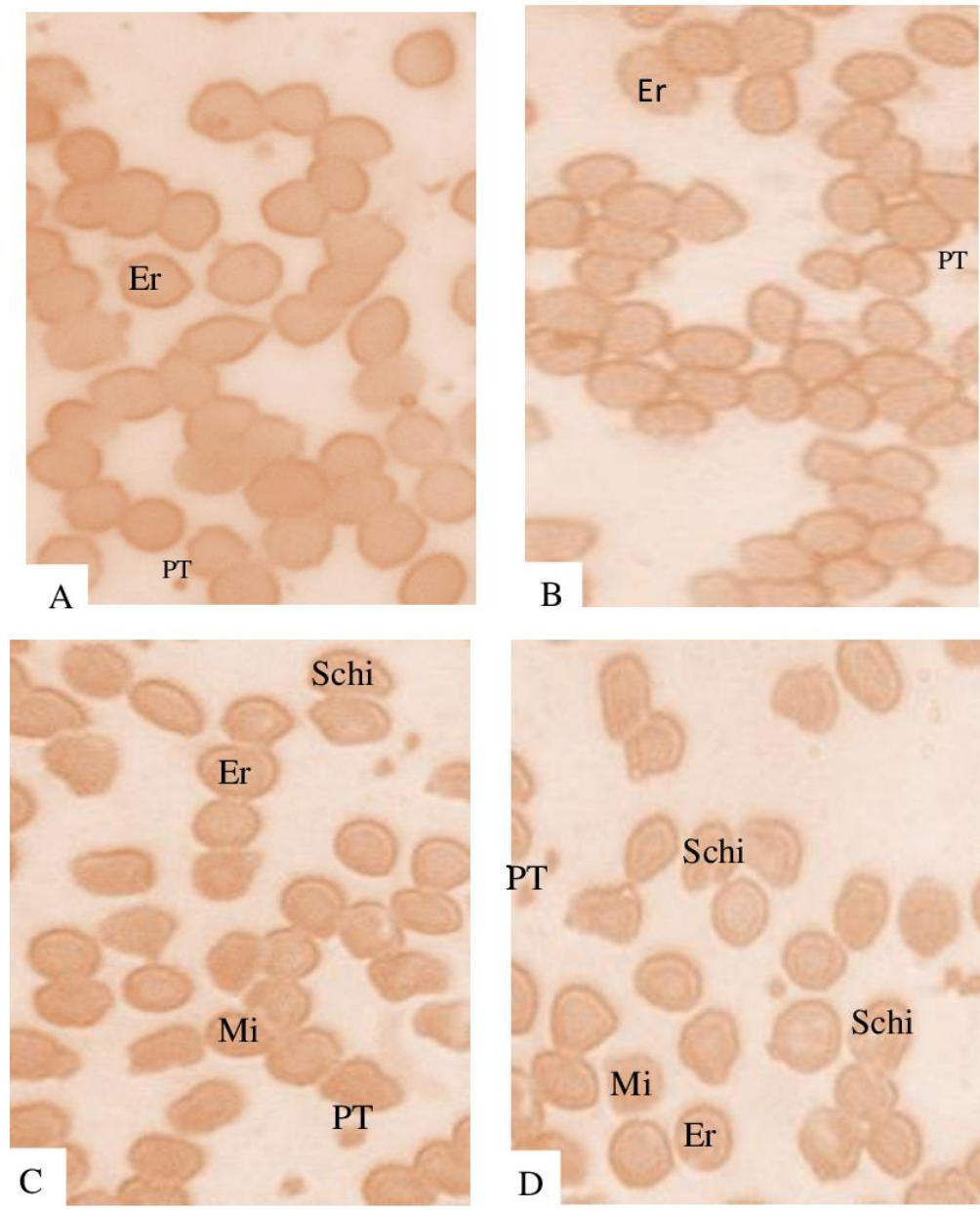

\section{Stained with May-Grünwald-Giemsa} MO, G x 100

$\boldsymbol{A}:$ Normal erythrocytes from the control batch. Er : Erythrocyte; PT : platelet $\boldsymbol{B}:$ Erythrocytes in the group treated with $500 \mathrm{mg} / \mathrm{kg}$ bw of AERv. C : Erythrocytes in the group treated with $700 \mathrm{mg} / \mathrm{kg}$ bw of AERv. Mi : Microcytosis. D: Erythrocytes du groupe treated with of $1000 \mathrm{mg} / \mathrm{kg}$ bw of AERv Schi : Schizocytes. MO: Optical microscope 
Fig.6 Blood smear from female rats
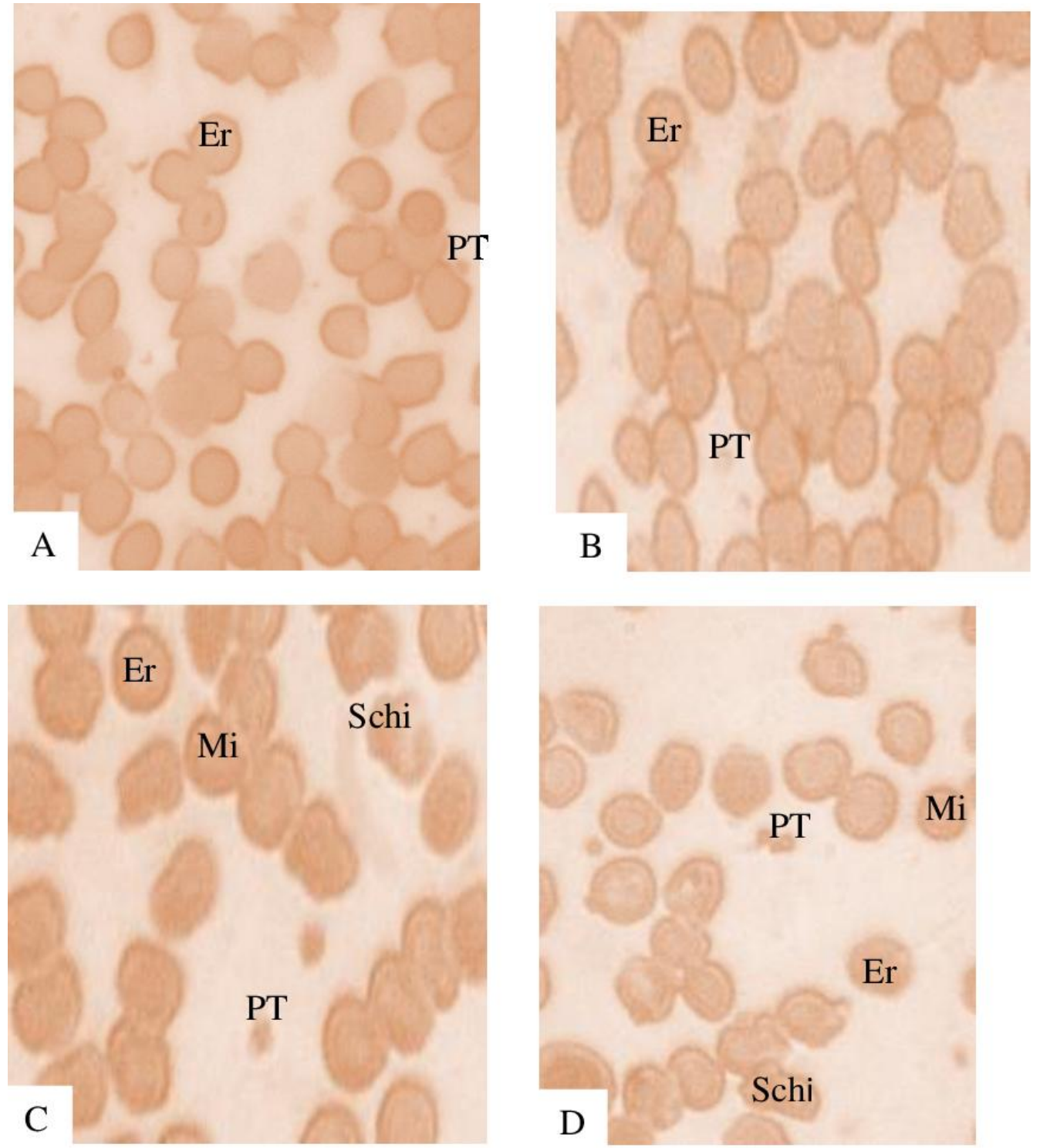

\section{Stained with May-Grünwald-Giemsa}

MO, G x 100

$\boldsymbol{A}$ : Normal erythrocytes from the control batch. Er: Erythrocyte; PT: platelet B: Erythrocytes in the group treated with $500 \mathrm{mg} / \mathrm{kg}$ bw of the extract. C : Erythrocytes in the group treated with $700 \mathrm{mg} / \mathrm{kg}$ bw of AERv. Mi :

Microcytosis. D: Erythrocytes du groupe treated with $1000 \mathrm{mg} / \mathrm{kg}$ bw of AERv. Schi : Schizocytes. MO: Optical microscope 
Table.1 Proportion of observed anomalies on blood smears

\begin{tabular}{|c|c|c|c|c|c|c|c|c|}
\hline \multirow{3}{*}{$\begin{array}{l}\text { Observed } \\
\text { anomalies } \\
\\
\text { SEX }\end{array}$} & \multicolumn{8}{|c|}{ Doses of extract administered $(\mathrm{mg} / \mathrm{kg} \mathrm{bw})$} \\
\hline & \multirow{3}{*}{$\begin{array}{c}\mathrm{M} \\
100\end{array}$} & \multirow{3}{*}{$\begin{array}{l}0 \\
\mathrm{~F} \\
100\end{array}$} & \multicolumn{2}{|c|}{500} & \multicolumn{2}{|c|}{700} & \multicolumn{2}{|c|}{1000} \\
\hline & & & M & $\mathrm{F}$ & M & $\mathrm{F}$ & M & $\mathrm{F}$ \\
\hline Normal smears (\%) & & & 100 & 100 & 90 & 80 & $30^{*}$ & $30^{*}$ \\
\hline $\begin{array}{c}\text { Microcytosis } \\
(\%)\end{array}$ & 0 & 0 & 0 & 0 & 0 & 0 & $40^{\mathrm{a}}$ & $50^{\mathrm{a}}$ \\
\hline $\begin{array}{c}\text { Schizocytes } \\
(\%)\end{array}$ & 0 & 0 & 0 & 0 & 10 & 10 & $30^{\mathrm{a}}$ & 20 \\
\hline
\end{tabular}

The values are expressed as a percentage; $\mathrm{n}=10$ rats; $\mathrm{M} 6=6$ months of administration, ${ }^{*}=\mathrm{p}<0.05 ; \mathrm{a}=\mathrm{p}<0.05$

Table.2 Effect of AERv on thrombocytes in male and female rats

\begin{tabular}{|c|c|c|c|c|c|}
\hline $\begin{array}{c}\text { Platelet } \\
\text { parameter }\end{array}$ & $\begin{array}{c}\text { Dose } \\
(\mathrm{mg} / \mathrm{kg} \\
\text { bw }\end{array}$ & Sex & Month 1 & $\begin{array}{c}\text { Period } \\
\text { Month } 3\end{array}$ & Month 6 \\
\hline \multirow{8}{*}{ 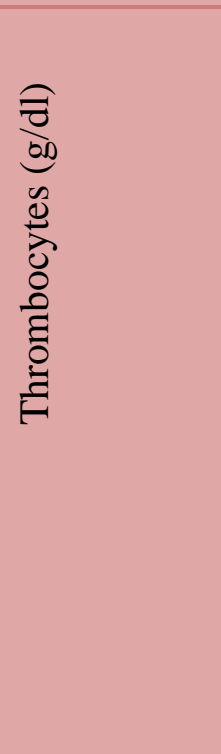 } & \multirow{2}{*}{0} & M & $587.5 \pm 1.09$ & $690.7 \pm 1.41$ & $718.3 \pm 1.83$ \\
\hline & & $\mathrm{F}$ & $577.2 \pm 3,23$ & $677.6 \pm 3.7$ & $698.6 \pm 5.1$ \\
\hline & & M & $587.1 \pm 8.74$ & $648.7 \pm 3.86 * * *$ & $578.6 \pm 3.89 * * *$ \\
\hline & & $\mathrm{F}$ & $577.1 \pm 5.71$ & $648.8 \pm 6.04 * * *$ & $619.3 \pm 6.1 * * *$ \\
\hline & & M & $586.8 \pm 5.54$ & $621.2 \pm 2.75 * * *$ & $507.1 \pm 1.39 * * *$ \\
\hline & & $\mathrm{F}$ & $576.9 \pm 8.14$ & $629.8 \pm 2.67 * * *$ & $572.9 \pm 3.91 * * *$ \\
\hline & & $\mathrm{M}$ & $586.1 \pm 7.08$ & $598.3 \pm 4.7 * * *$ & $405.1 \pm 3.17 * * *$ \\
\hline & & $\mathrm{F}$ & $576.6 \pm 1.2$ & $610.9 \pm 2.51 * * *$ & $435.6 \pm 2.99 * * *$ \\
\hline
\end{tabular}

$\mathrm{n}=20$ rats; $\mathrm{M} 1, \mathrm{M} 3$ and $\mathrm{M} 6=1,3$ and 6 months of administration;*** $=\mathrm{p}<0.001$ 
Table.3 Reversible effect of AERv on haematological parameters in male and female rats

\begin{tabular}{|c|c|c|c|c|}
\hline \multirow{2}{*}{$\begin{array}{l}\text { Haematological } \\
\text { parameters }\end{array}$} & \multirow{2}{*}{$\begin{array}{l}\text { Dose }(\mathrm{mg} / \mathrm{kg} \\
\text { bw) }\end{array}$} & \multirow[t]{2}{*}{ Sex } & \multicolumn{2}{|c|}{ Period } \\
\hline & & & Month 6 & Month 7 \\
\hline \multirow[t]{4}{*}{ Erythrocytes $\left(10^{6} / \mu \mathrm{l}\right)$} & \multirow[t]{2}{*}{0} & M & $9.37 \pm 0.03$ & $9.35 \pm 0.02$ \\
\hline & & $\mathrm{F}$ & $8,71 \pm 0,09$ & $8.68 \pm 0.12$ \\
\hline & \multirow[t]{2}{*}{1000} & M & $8.99 \pm 0.06 * *$ & $9.32 \pm 0.01$ \\
\hline & & $\mathrm{F}$ & $7.9 \pm 0.08^{* * *}$ & $8.69 \pm 0.09$ \\
\hline \multirow[t]{4}{*}{ Hemoglobin $(\mathrm{g} / \mathrm{dl})$} & \multirow[t]{2}{*}{0} & $\mathrm{M}$ & $14.02 \pm 0.12$ & $13.64 \pm 0.05$ \\
\hline & & $\mathrm{F}$ & $13.46 \pm 0.58$ & $13.26 \pm 0.06$ \\
\hline & \multirow[t]{2}{*}{1000} & M & $13.43 \pm 0.04 *$ & $13.52 \pm 0.13$ \\
\hline & & $\mathrm{F}$ & $12.98 \pm 0.07$ & $13.22 \pm 0.08$ \\
\hline \multirow[t]{4}{*}{ Hematocrit (\%) } & \multirow[t]{2}{*}{0} & M & $58.55 \pm 0.42$ & $56.7 \pm 0.26$ \\
\hline & & $\mathrm{F}$ & $50.76 \pm 0.5$ & $50.7 \pm 0.73$ \\
\hline & \multirow{2}{*}{1000} & $\mathrm{M}$ & $50.76 \pm 1.39 * * *$ & $56.5 \pm 0.12$ \\
\hline & & $\mathrm{F}$ & $40.29 \pm 0,43 * * *$ & $50.7 \pm 0.49$ \\
\hline \multirow[t]{4}{*}{ Thrombocytes (g/dl) } & \multirow[t]{2}{*}{0} & M & $718.3 \pm 1.83$ & $733 \pm 2.72$ \\
\hline & & $\mathrm{F}$ & $698.6 \pm 5,1$ & $716.4 \pm 3.14$ \\
\hline & \multirow{2}{*}{1000} & $\mathrm{M}$ & $405.1 \pm 3.17 * * *$ & $730.4 \pm 2.25$ \\
\hline & & $\mathrm{F}$ & $435.6 \pm 2.99 * * *$ & $713.4 \pm 4.28$ \\
\hline \multirow[t]{4}{*}{ Leukocytes $\left(10^{3} / \mu 1\right)$} & \multirow[t]{2}{*}{0} & $\mathrm{M}$ & $9.92 \pm 0.06$ & $10.296 \pm 0.032$ \\
\hline & & $\mathrm{F}$ & $9.45 \pm 0.13$ & $9.39 \pm 0.0308$ \\
\hline & \multirow[t]{2}{*}{1000} & $\mathrm{M}$ & $10.63 \pm 0.15^{\mathrm{c}}$ & $9.446 \pm 0,0462 * * *$ \\
\hline & & $\mathrm{F}$ & $10.05 \pm 0.03^{\mathrm{c}}$ & $9.408 \pm 0.034$ \\
\hline
\end{tabular}

$\mathrm{n}=10$ rats; $\mathrm{M} 6 ; \mathrm{M} 7=6$ and 7 months of administration

$*=\mathrm{p}<0.05 ; * *=\mathrm{p}<0.01 ; * * *=\mathrm{p}<0.001 ; \mathrm{b}=\mathrm{p}<0.01 ; \mathrm{c}=\mathrm{p}<0.001$

The presence of these metabolites in a large quantity in AERv at the high dose administered over a long period (six months) could justify the drop in the level of erythrocytes and erythrocyte indices such as hematocrit and hemoglobin. Morphological analyse showed the blood smear with schizocytes mainly in particular in the groups of rats treated at the dose of 700 and 1000 $\mathrm{mg} / \mathrm{kg}$ bw of the extract both in males and females. In addition, our results revealed a drop at the end of the administration period in the hemoglobin level of male rats while in females no change in these parameters was recorded at the dose of $1000 \mathrm{mg} / \mathrm{kg}$ of bw, in rats, these variations can result from variations of each individual within the same group which would not be under the effect of the extract (Inala et al., 2002). The present study results are in agreement with those of Sireeratawong et al., (Sireeratawong et al., 2013) who conducted a chronic toxicity study of aqueous extract of dried fruits of Terminalia bellerica in Spargue-Dawley rats. AERv causing no decrease in erythrocytes and some erythrocyte indices after three months of administration would be non-toxic during this period at all doses. Our results do not agree with those of Mukinda T. and Syce J. (2007) who showed in their work that the aqueous extract of Artemisia afra did not cause any disturbance of the erythrocyte line at a dose of $1000 \mathrm{mg} / \mathrm{kg} \mathrm{bw}$ of the extract after three months of administration and therefore would not be toxic to circulating blood cells, also did not interfere with erythropoiesis. In terms of 
leukocyte parameters, an increase in the leukocyte line was observed. Overall, this increase in the leukocyte line could be explained by a strengthening of the immune system (Martini et al., 2012). Our results disagree with those of Olorunnisola et al., (2012) who evaluated the subchronic toxicity of the methanolic extract from the rhizomes of Tulbaghia violacea in rats which did not alter the leukocyte parameters. As for the thrombocytes, a very significant decrease in a dose-dependent manner from the third month (month 3) in all the rats treated compared to the controls suggested a destruction of the platelets or an inhibition of the production of platelets by an administration. repeated AERv but an inhibitory effect on a strong platelet aggregability (Mohammad and Woodward, 1986). These results disagree with those obtained by Iskandar et al.,(2017) who showed in a chronic toxicity study that the aqueous extract of the pulp of Tamarindus indica did not cause any disturbance at the high dose of $1000 \mathrm{mg} / \mathrm{kg}$ bw on the thrombocytes.. After stopping the administration of AERv, the effects observed at the high dose are reversible in erythrocyte and thrombocyte parameters and a normalization of blood tissue integrity but a delayed effect on leukocytes.

Oral administration of the aqueous extract of the barkless roots of Rauvolfia vomitoria could not be toxic on the rats' haematological parameters at the therapeutic dose $(700 \mathrm{mg} / \mathrm{kg}$ bw) after six months of administration. This plant would, therefore, be safe in the treatment of diabetes. However, biochemical and anatomo-histopathological studies should be considered in order to guarantee the total safety of Rauvolfia vomitoria.

\section{Acknowledgments}

The authors would like to thank all the members of the Physiology, Pharmacology and Pharmacopoeia Laboratory, Training and Research Unit of Sciences of Nature (Nangui Abrogoua University), for their encouragement, and technical assistance.

\section{References}

Adjanohoun E. et Aké Assi L. (1979). Contribution au recensement des plantes médicinales de la Côte d'Ivoire. C.R.E.S Univ. Abidjan, Centre National de Floristique ; 358 p.

Aké Assi L. et Guinko S. (1991). Plantes utilisées dans la médecine traditionnelle en Afrique de l'Ouest. Roche Basel : Switzer land; 127p.

Aké Assi L. (1983). Médecine traditionnelle et pharmacopée. Rapport sur le colloque international sur la médecine traditionnelle africaine, Abidjan, Côte d'Ivoire. Bull Med Trad Pharm ACCT; 4(2): 203-206.

Arias M., Quijano J., Haridas V., Gutterman J. and Lemeshko V. (2010). Red blood cell permeabilization by hypotonic treatment, saponin, and anticancer avicins. Biochem Phy Act, p. 11891196.

Food and Drug Administration (FDA). (1999). International Conference on Harmonisation; guidance on the duration of chronic toxicity testing in animals (rodent and nonrodent toxicity testing); Availability. Fed Reg.122 (64): 34259-34260.

Gomé M. B., Kouakou K., Touré A. et Traoré F. (2011). Etude de la toxicité aiguie et subchronique de l'extrait aqueux de Passiflora foetida L. (Passifloraceae) chez les rats et les souris. Inter. J. Biol. Chem. Sci. 5(5):1777-1789.

Inala P., Sirimontaporn A., Inpunkaew R., Rungrojejinda K., Kengkoom K., Ratanasak W,. and Buripakdi L. (2002). Hematological analysis of outbred Sprague-Dawley rat in the 
Facility of National Laboratory. $28^{\text {th }}$ Congress on Science and Technology of Thailand.

Iskandar I., Setiawan F., Sasongko L. and Adnyana K. (2017)Six-Month Chronic Toxicity Study of Tamarind Pulp (Tamarindus indica L.) Water Extract. Sci. Pharm.10p.

Kouassi, K., Adjambri, A., Koné M., Sawadogo, D. and Yapo, A. (2018). Influence of aqueous extract of Sacoglottis gabonensis (Baille) urban (Humiriaceae) of Buruli ulcer, on anthropométric and hematological parameters in Wistar rat.Pharm Innov J. 7(3) :104-110.

Langford k., Luchtman L., Miller R., and Walk, D. (2003). Performance evaluation of the Sysmex XT-2000 i automated hematology analyzer. $L a b$ Hem; 9 (1) : 29-37.

Martini F., Nath J., and Bartholomew E. (2012). Fundamentals of Anatomy and Physiology, 9th edition; Pearson: San Fransisco, CA, USA. ; Pp : 642-645.

Mukinda T. and Syce J. (2007) Acute and chronic toxicity of the aqueousextract of Artemisia afra in rodents. $J$. Ethnopharm. Pp :138-144.

Mohammad S. and Woodward S. (1986). Characterisation of a potent inhibitor of platelet agregation and release reaction isolated from Allium sativum (Garlic). Thromb Res 44 : 793-806.

N'Doua L., Abo K., Aoussi S., Kouakou
L.and Ehilé E. (2016). Aqueous Extract of Rauwolfia Vomitoria Afzel (Apocynaceae) Roots Effect on Blood Glucose Level of Normoglycemic and Hyperglycemic Rats. Amer. Sci Res Jour Eng Tech Sci (ASRJETS). 20 (1): $66-77$.

Neuwinger H. D. (1996). African ethnobotany, poisons and drugs. Chem. Pharm. Toxicol. Londres. 941 p.

OCDE. (2009). Projet de ligne directrice de l'OCDE pour les essais de produits chimiques No 452. OCDE, Paris, 16p.

Olorunnisola O., Bradley G. and Afolayan A. (2012). Acute and sub-chronic toxicity studies of methanolic extract of Tulbaghia violacea rhizhomes in Wistar rats Afr Jour Biotech. 11(83) : 14934-14940.

OMS. (2002). Promotion du rôle de la médecine traditionnelle dans le système de santé: strategies de la région africaine. AFR/RC50/9. Pp 1215.

Sireeratawong S., Jaijoy K., Panunto W., Nanna U. and Lertprasertsuke N. (2013). Acute and chronic toxicity studies of the water extract from dried fruits of Terminalia bellerica (gaertn.) roxb. in spargue-dawley rats. Afr. $J$. Trad. Compl. Altern. Med.10(2):223231.

Waynforth H. B. (1980). Experimental and Surgical Technique in the Rat. Sec Ed Acad Pr Lond; pp. 3-61.

\section{How to cite this article:}

Roland Patrick N'Cho, Mama Koné, Moussa Gbogbo, N'Guessan Jean Baptiste Oussou and Angoué Paul Yapo. 2021. Chronic Toxicity Study of Aqueous Roots Extract of Rauvolfia vomitoria AFZEL on Haematological Parameters in Wistar Rats. Int.J.Curr.Microbiol.App.Sci. 10(09): 567-577. doi: https://doi.org/10.20546/ijcmas.2021.1009.065 